\title{
DYE REMOVAL FROM TEXTILE WASTE WATER THROUGH THE ADSORPTION BY PUMICE USED IN STONE WASHING
}

\author{
Aysegül Ekmekçi Körlüa, Saadet Yapar ${ }^{b}$, Seher Perinçek ${ }^{c}$, Hatice Yılmaz ${ }^{d}$, Cem Bağıran ${ }^{e}$ \\ aEge University Engineering Faculty, Textile Engineering Department, Bornova, Izmir, 35100, Turkey, Tel:+90 2323112755 , Fax:+90 2323399222 \\ ${ }^{b}$ Ege University Engineering Faculty, Chemical Engineering Department, Bornova, Izmir, 35100, Turkey, Tel:+90 2323112459, Fax:+90 2323887776 \\ 'Ege University, Emel Akın Vocational Training School, Bornova, Izmir, 35100, Turkey, Tel:+90 23231116 08, Fax:+90 2323426053 \\ dDokuz Eylül University, Engineering Faculty, Mining Engineering Department, Buca, İzmir, 35160, Turkey, Tel:+90 2323017547 , Fax:+90 2324530868 \\ eEge University, Graduate School of Natural and Applied Sciences, Bornova, Izmir, 35100, Turkey, Tel:+90 5436201937 , Fax:+90 2565211270 \\ corresponding author e-mail: aysegul.ekmekci@ege.edu.tr
}

\begin{abstract}
:
Because the waste production is inevitable in almost all industries, the elimination of these wastes is a requirement in terms of environmental regulations and welfare of all the creatures in the future. In this study, the use of the waste pumice stones of a denim washing mill is intended to eliminate the pollutant by a waste material and obtain economic benefits by converting it to the adsorbent. The pollutants in the effluents obtained from three different localisations of waste water treatment system of the same factory were removed through the adsorption. The experimental studies were carried out in three different steps; characterisation of adsorbent before and after adsorption; adsorption isotherm studies and biological oxygen demand (BOD), chemical oxygen demand (COD) measurements. Characterisation studies showed that the waste pumice has almost the same structural properties with unused one except the existence of some organic residues coming from washing process. The results of adsorption studies conducted at the adsorbent concentrations changing from 5 to $35 \mathrm{~g} / \mathrm{l}$ revealed that the decolourisation was initial dye-concentration dependent. According to the $B O D$ and $C O D$ measurements, the supernatants obtained at the end of adsorption could be assumed as somewhat polluted and this result indicates that the organic impurities other than indigo were also removed through the adsorption.
\end{abstract}

\section{Keywords:}

Denim, stone washing, indigo as adsorbate, pumice stone, adsorption, waste water, waste water treatment

\section{Introduction}

The textile wet processing or finishing industry consumes enormous amounts of water and auxiliary chemicals primarily in the dyeing and finishing operations [1-5]. While many of these chemicals become part of the product, some are removed from the fabric, ending up in waste water.

Approximately $12 \%$ of synthetic dyes used each year during manufacture and processing operations in the textile industry are lost and $20 \%$ of these lost dyes enter the environment through effluents. Between 5 and $20 \%$ of the indigo dye used in the blue jeans industry is lost to the effluent, resulting in an effluent high in colour, suspended solids (salts) and dissolved organics [3]. Some of these constituents impart inherent toxicity to the effluent, are aesthetically displeasing, damage the quality of receiving streams and may be toxic to treatment processes, to food chain organisms and to aquatic life. Discharged waste water containing dyes reduces the conductivity of light necessary for the photosynthesis of primary producers living in water and thus, seriously harms ecosystems [4]. Various processes have been utilised to remove the coloured colloidal bodies and suspended solids and to reduce the associated high biological oxygen demand (BOD). Consistent with the high variability of the characteristics of textile waste waters, many different physical, chemical and biological treatment methods have been employed for the treatment. However, no single treatment system is adequate to degrade the dye structures in waste waters. A significant disadvantage of the current processes is their high capital and operating costs [1]. They may also place at risk permit renewal for the concerned industries [5]. Such waste water streams often do not meet regulatory standards for waste water discharge even after undergoing treatment by conventional means. In essence, dealing with the removal or recovery of dyes and salts from textile effluent is a worldwide problem [1].

Adsorption on the other hand is rapidly becoming a prominent method of treating aqueous effluents and has been extensively used in industrial processes for a variety of separation and purification purposes, especially in the removal of coloured and colourless organic pollutants from industrial waste water and especially from textile waste water $[6,7]$. Although the pollutants are transferred from liquid to solid medium, adsorption process is a remedy for the environmental protection because of the capture and entrapment of these materials in a small volume. The pollutants loaded to the adsorbents are removed by using different techniques such as thermal treatment, chemical treatment, etc. $[8,9]$. These materials could also be used in the construction of housing, public buildings and roads and thus their consumption in this area is another solution for the waste adsorbents $[8,10]$. 
It also should be noted, however, that the applicability of the adsorption process is largely dependent on the availability of cheap adsorbents and thus, recent initiatives in adsorption process have targeted reaching economically reasonable adsorbents. In addition to naturally occurring minerals like pumice stone, clay, zeolite; some of industrial or agricultural wastes like peat, coal ashes, rice husk, tree barks, wood chips are assumed to be low-cost adsorbents. They are used for removal of dye and organic coloured matter from textile effluents (i.e. a removal of $40-90 \%$ basic dyes and $40 \%$ direct dyes, with maximum adsorption capacities for basic dyes of $338 \mathrm{mg} / \mathrm{g}$ ) [7, 11, 13-19]. Pumice is a very interesting adsorbent. Natural and alkali-modified pumice adsorbents can be used for softening of hard water. Pumice adsorbents showed a higher selectivity for calcium adsorption compared to magnesium, especially [12]. Contrary to the works reported in the literature; the pumice used in this study is the waste of stone washing process.

Pumice is an amorphous, porous volcanic rock, which is composed mainly of $\mathrm{SiO}_{2}$. It has high porosity and, as a result, low apparent density $\left(0.35-0.65 \mathrm{~g} / \mathrm{cm}^{3}\right)$ in aggregate form. Because of its high porosity and surface area, the use of natural and/or modified pumice as an adsorbent for the removal of organic (phenol, textile dyes) and inorganic (various heavy metals and radioactive elements) water pollutants is currently under research [20-22].

Undyed denim is nearly white in colour. For production of blue jeans, it is dyed with an indigo-based dye, colouring the fabric dark blue. Traditionally, the stone-washed look in denim fabric or jeans involves washing the garments in the presence of pumice stones and/or enzymes (cellulaselaccase cocktails) to generate the desired localised erosion of the fabrics, followed by a partial bleaching treatment with sodium hypochlorite and neutralising and several rinsing steps [1]. Stone washing process is still popular in denim washing mills because pumice stone is cheaper than enzymes and abundant in Turkey.

The 'stonewashing' process for the degradation of blue indigo results in excessive amounts of indigo being removed from the fabrics into the discharged waste water. Colour is highly visible even in concentrations as low as $1 \mathrm{ppm}$ for most dyes, eliciting complaints from an increasingly environmentally aware public and often failing to meet regulatory requirements for waste water discharge [1]. Waste water containing indigo is characterised by a moderate amount of chemical oxygen demand (COD), $\mathrm{pH}$, suspended solids, dissolved solids and a dark blue colour. Although colour and COD are some of the important parameters monitored to meet effluent discharge standards, companies are discouraged from treating or recovering the waste dye by cost implications [23].

The aim of the study is the use of waste pumice stones obtained from denim washing mills for treatment of the effluent of the same mills. Waste pumice stone is brought into economy and waste water load is reduced. Novelty of the study is the use of waste pumice stone from denim washing mill as absorbents in treatment of the same denim washing mill effluent.

\section{Experiment}

\subsection{Materials}

The experiments were conducted by using the samples obtained from waste water treatment system of a denim washing mill founded in Söke, Turkey. The samples were collected from three different parts of the system. First two samples, Effluent 1 and Effluent 2, were obtained from the inlet and outlet of the stabilisation tank, respectively. Effluent 3 was obtained from the exit of the biological treatment unit. Shown in Table 1 are the properties of waste water change depending on the location in the treatment system.

The solutions of the chemicals used in denim washing were prepared according to concentration in denim washing and COD values of the treated and untreated solutions were measured.

Table 1: Properties of Effluents

\begin{tabular}{|c|c|c|c|}
\hline Effluent & $\begin{array}{c}\text { Initial dye } \\
\text { concentration } \\
\text { (ppm) }\end{array}$ & COD mg/l & $\begin{array}{c}\text { Total } \\
\text { suspended } \\
\text { solid mg/l }\end{array}$ \\
\hline 1 & 30 & 1300 & $450-500$ \\
\hline 2 & 7 & 800 & $20-30$ \\
\hline 3 & $\sim 0$ & $80-120$ & $12-15$ \\
\hline
\end{tabular}

COD: Chemical oxygen demand

In addition to the waste water samples, pumice stone used in the adsorption studies was also obtained from the same factory as a waste of stone washing units. The waste pumice stone was used in stone washing processes until they were becoming unusable in stone washing of denim. It was used without further treatment except grinding and pulverisation to pass through a $595 \mathrm{~mm}$ sieve.

All reagents used for waste water treatment were of analytical grade. The chemicals used in denim washing (Table 3 ) were industrial grade.

\subsection{Methods}

\section{Characterisation studies}

Because the stone washing is carried out by using some detergents containing surfactants playing different roles such as wetting agents, the pumice stone particles obtained as a waste of washing process and named as used were subjected to Attenuated total reflectance-Fourier transform infrared (ATR-FTIR), X-ray diffraction (XRD), Energy-dispersive X-ray spectroscopy (EDS) and scanning electron microscope (SEM) analyses before adsorption experiments for characterisation. The same analyses were repeated by unused pumice stone obtained from the same factory.

XRD analyses were conducted by using a Rigaku Miniflex II $\mathrm{X}$-Ray Diffractometer Cu $\mathrm{K}_{\mathrm{a}}$ radiation and Ni filter. XRD patterns 
were recorded for $2 \mathrm{q}$ from 0 to $80^{\circ}$ at a scan rate of $2 \% \mathrm{~min}$ at $30 \mathrm{kV}$ and15 $\mathrm{mA}$.

A JEOL JXA 733 Superprobe-type SEM was used to determine the morphologies of used and unused pumice stones. EDS analyses were also conducted to estimate the components in the samples.

ATR-FTIR analyses were conducted in a Perkin Elmer Spectrum 100 FTIR spectrometer. The pellets were prepared by compressing approximately $1 \mathrm{mg}$ of the samples dispersed in $100 \mathrm{mg}$ of $\mathrm{KBr}$ matrix at $167 \mathrm{MPa}$. Then, each pellet was thermally treated at $40^{\circ} \mathrm{C}$ for 24 hours in an oven to remove the moisture. Finally, the pellets were introduced and stored in a drying device until the ATR-FTIR measurement. The spectra were measured with an average of 4 scans and a resolution of $4 \mathrm{~cm}^{-1}$.

\section{Adsorption experiments}

The amount of dye removed was determined by conducting the batch adsorption experiments. The experiment conditions were determined by considering the industrial operations. Therefore, the shaking time was limited to 3 hours and waste water was used as obtained to keep the operation costs minimum. Various amounts of pumice stone chancing from 0.2 to $3.5 \mathrm{~g}$ were added to $100 \mathrm{ml}$ of waste water. The dispersions shaken for 3 hours at $20^{\circ} \mathrm{C}$ were centrifuged and supernatants were analysed in a JASCO 7000 UV spectrophotometer at $665 \mathrm{~nm}$.

\section{BOD and COD Measurements}

$\mathrm{pH}, \mathrm{COD}$ and BOD measurements were accomplished by using the supernatants collected at the end of adsorption studies carried out using Effluent 2. COD values of treated and untreated solutions of chemicals used in denim washing were measured in order to determine their adsorbability. $\mathrm{pH}$ and conductivity measurements were carried out by using a $\mathrm{pH}$ meter 2005 (J.P. Selecta, Barcelona, Spain).

BOD was measured with an Oxitop IS 12 (WTW, Weilheim, Germany) system, following the instructions of the manufacturer. The $\mathrm{BOD}_{5}$ test also requires a 5-day incubation

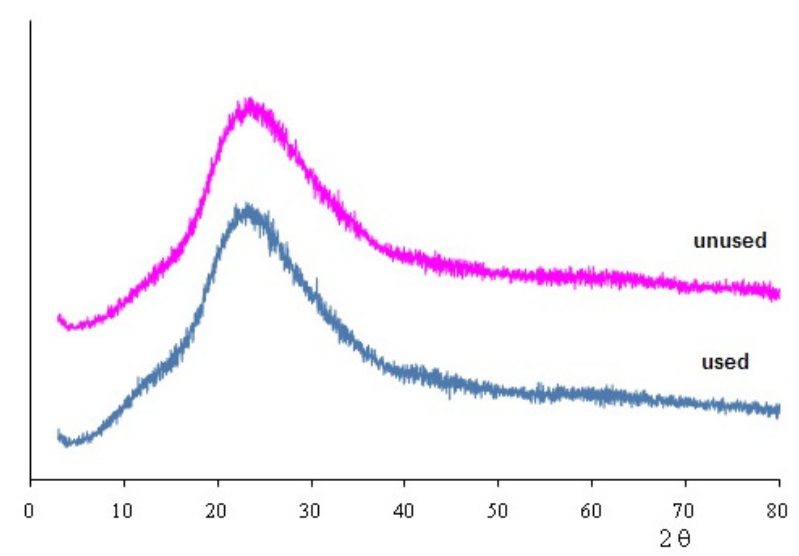

Figure 1: The XRD spectra of used and unused pumice stones XRD: X-ray diffraction period while COD results are completed on the same day. COD of the test solutions was established using a Spectroquant TR 320 reactor (Merck, Darmstadt, Germany) and a Spectroquant Picco Colorimeter (Merck, Darmstadt, Germany). COD was determined with Spectroquant $®$ spectrophotometric kits (Merck, Darmstadt, Germany) covering the range of 25-1500 $\mathrm{mg} \mathrm{l}^{-1}$ in accordance with the instructions of the manufacturer.

\section{Results and discussion}

\subsection{Characterisation studies}

The results of the XRD analyses are given in Figure 1. As shown in the figure, the spectra of used and unused samples have the same features, only a dome is observed between $2 q=5$ and $40^{\circ}$ indicating the presence of only amorphous phase in both samples [12].

Figure 2 shows the ATR-FTIR spectra of unused and used pumice stones at wave numbers in $4500-500 \mathrm{~cm}^{-1}$. Both spectra have the adsorption bands at approximately $1055 \mathrm{~cm}^{-1}$ and 785 $\mathrm{cm}^{-1}$ that are assigned to the symmetric stretching vibration of $\mathrm{Si}-\mathrm{O}-\mathrm{Si}$ and bending vibration of $\mathrm{Si}-\mathrm{O}$ bonds, respectively [12]. The broadening peak at approximately $3626 \mathrm{~cm}^{-1}$ is attributed to $\mathrm{Al}-\mathrm{Al}-\mathrm{OH}$ stretching [24] and also asymmetric stretching vibration of $\mathrm{H}-\mathrm{O}$ bond of adsorbed water molecules [12]. Other peak observed at approximately $1636 \mathrm{~cm}^{-1}$ is also owing to the bending vibration of $\mathrm{H}-\mathrm{O}-\mathrm{H}$ bond in adsorbed water molecules. The appearance of two new bands in the spectrum of used pumice was attributed to the existence of organic residues coming from the washing process because the bands at approximately $2941 \mathrm{~cm}^{-1}$ and $28,532 \mathrm{~cm}^{-1}$ correspond to asymmetric and symmetric stretching vibrations of $\mathrm{C}-\mathrm{H}$ bonds, respectively.

SEM micrographs showing the surface morphology of the unused and used pumice stones at magnification $600 \times$ are given in Figure 3. A close examination of the figure reveals that the structure of pumice resembles rose petals in both cases. The surface has an irregular and porous texture with large grain and sharp edges. The EDS analyses showed that $\mathrm{SiO}_{2}$ is the main component and some particles contain only $\mathrm{SiO}_{2}$,

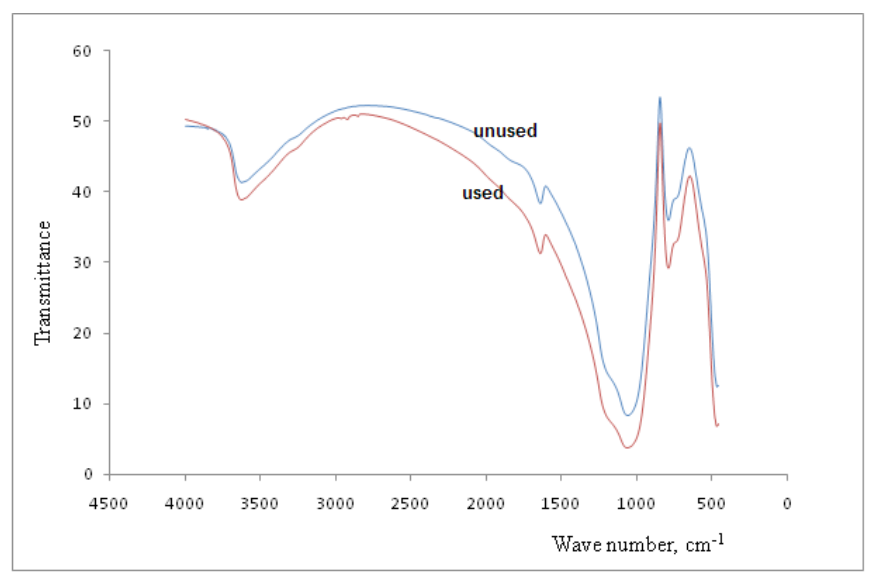

Figure 2: The ATR- FTIR spectra of unused and used pumice stones. 
a)

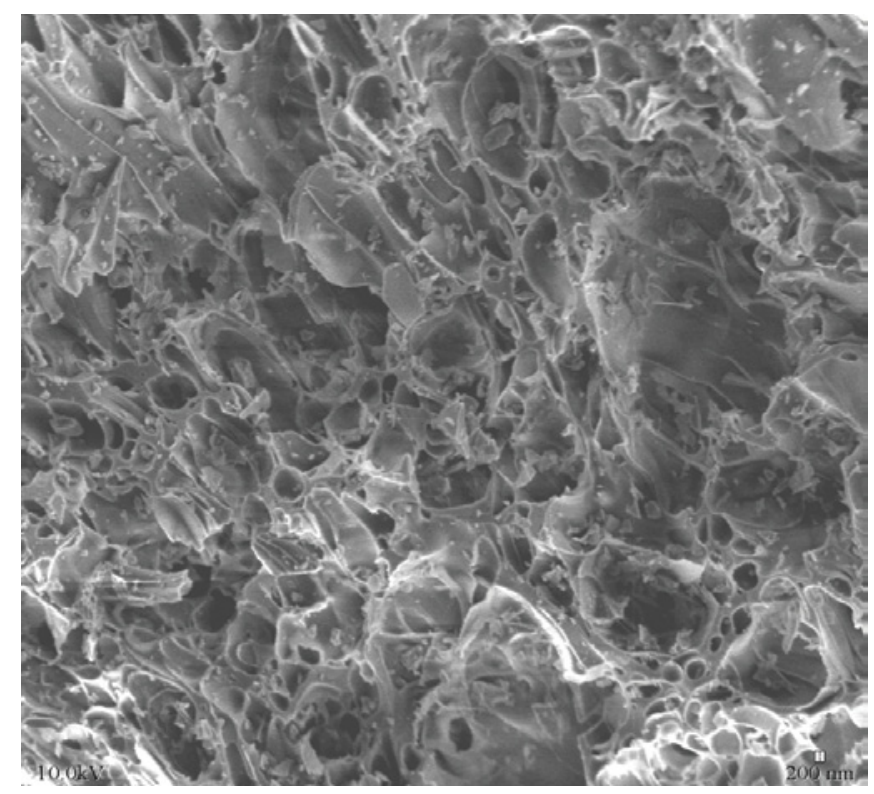

b)

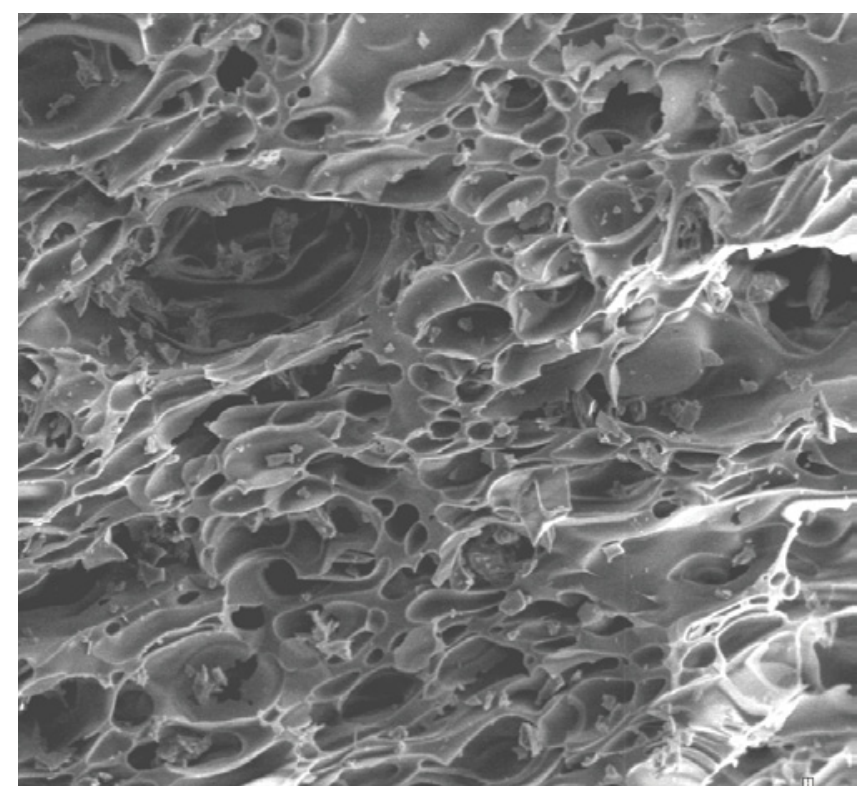

Figure 3: The surface morphology of the unused (a) and used (b) pumice stones

while $\mathrm{Al}_{2} \mathrm{O}_{3}, \mathrm{Na}_{2} \mathrm{O}, \mathrm{K}_{2} \mathrm{O}$ and $\mathrm{MgO}$ are also determined in minor amounts in some other particles.

\subsection{Isotherm studies}

The results of the studies are given in Figure 4. Although the percent removal increases with increasing amount of adsorbent, the curves have rather different shapes indicating the initial dye concentration dependence of the adsorption. When the initial dye concentration is $7 \mathrm{ppm}$, the percent removal increases abruptly at very low adsorbent concentrations and reaches approximately $76 \%$ for $5 \mathrm{~g} / \mathrm{l}$ adsorbent concentration. The increase in the percent removal is very slow at concentrations exceeding $5 \mathrm{~g} / \mathrm{l}$ and reaches almost $100 \%$ at $35 \mathrm{~g} / \mathrm{l}$ adsorbent concentration. On the other hand, the increase in percent removal with the adsorbent concentration is almost linear at 30 ppm initial dye concentration but less than the percent removal obtained at lower initial concentration.

\subsection{COD and BOD measurements}

The results of the measurements are given in Table 2. Sample 1 represents the untreated Effluent 2 and the other samples are the supernatants obtained during isotherm studies conducted by using different amounts of adsorbents. As shown in the table, the supernatants have higher $\mathrm{pH}$ values than the waste water. Depending on the adsorbent concentration, the COD values decrease between 43 and $68 \%$ and the supernatants, except Sample 2, have the lower initial BOD values. BOD values of waste water and supernatants increase for the following days but the increase in BOD values of waste water is tremendous, whereas it is almost negligible in supernatants. Although BOD is the amount of dissolved oxygen needed by aerobic biological organisms in a body of water to break down organic material present in given water sample, it is also used for a rough estimation of degree of organic pollution. Therefore, the higher $B O D$ values are attributed to the existence of more organic

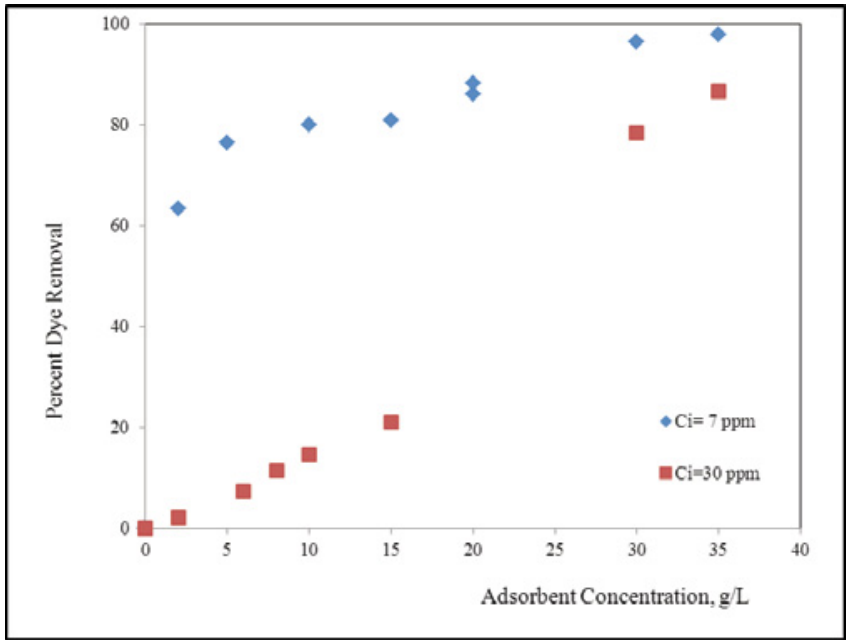

Figure 4: The effect of adsorbent concentration on dye removal from the waste water

compounds in the water and water taken from the outlet of the stabilisation tank is very polluted. On the other hand, the supernatants could be assumed as somewhat polluted and this result indicates that the organic impurities other than indigo were also removed through the adsorption.

COD values of pure chemical and auxiliary solutions are given in Table 3. The concentrations of the solutions were different from each other, because the amounts of the chemicals and auxiliaries in denim washing recipes were different in the mill. Adsorbent is effective for all the chemicals and auxiliaries. Reduction of COD is between 3.59 and 51.27.

\section{CONCLUSION}

In this work, the removal of indigo from the textile effluent by waste pumice stone from a denim factory was studied and it was concluded that the stone has the potentialities to be used 
Table 2: The COD and BOD values of treated Effluent 2

\begin{tabular}{|c|c|c|c|c|c|c|c|c|}
\hline \multirow{2}{*}{ Sample } & \multirow{2}{*}{$\begin{array}{c}\text { Adsorbent } \\
\text { concentration } \\
(\mathrm{g} / \mathrm{l})\end{array}$} & \multirow{2}{*}{$\mathrm{pH}$} & \multirow{2}{*}{$\begin{array}{l}\text { COD } \\
\text { (mg/l) }\end{array}$} & \multicolumn{5}{|c|}{ BOD (mg/l) } \\
\hline & & & & $1^{\text {st }}$ day & $2^{\text {nd }}$ day & $3^{\text {rd }}$ day & $4^{\text {th }}$ day & $5^{\text {th }}$ day \\
\hline 1 & 0 & 6.9 & 878 & 12 & 280 & 360 & 380 & 420 \\
\hline 2 & 5 & 8.06 & 501 & 12 & 14 & 16 & 16 & 18 \\
\hline 3 & 10 & 8.16 & 460 & 10 & 12 & 14 & 14 & 16 \\
\hline 4 & 30 & 8.13 & 277 & 6 & 8 & 8 & 8 & 8 \\
\hline
\end{tabular}

BOD: Biological oxygen demand; COD: Chemical oxygen demand

Table 3: The COD of solutions of chemicals and auxiliaries used in denim washing processes

\begin{tabular}{|c|c|c|c|c|}
\hline \multirow{2}{*}{ Chemicals/auxiliaries/enzymes } & \multirow{2}{*}{$\begin{array}{c}\text { Concentration } \\
\text { of the solutions } \\
\mathbf{( g / l )}\end{array}$} & $\begin{array}{c}\text { Untreated } \\
\text { solution }\end{array}$ & Treated solution & $\begin{array}{c}\text { Reduction of } \\
\text { COD (\%) }\end{array}$ \\
\cline { 3 - 5 } Hydroxylammonium sulphate & 0.06 & 77.4 & 58 & 25.065 \\
\hline Dispersing agent & 0.6 & 152 & 28.8 & 19.74 \\
\hline Micro-silicon emulsion-based softening & 0.02 & 59.1 & 39 & 31.27 \\
\hline agent & 0.06 & 57.6 & 29.6 & 32.29 \\
\hline Cationic fixing agent & 0.006 & 35.9 & 32.2 & 3.5 \\
\hline Macro-silicon emulsion-based softening & 0.005 & 33.4 & 32.5 & 3.59 \\
\hline agent & 0.025 & 49.6 & 26.7 & 34.48 \\
\hline Neutral cellulase enzyme 1 & 0.004 & 35.6 & 25 \\
\hline
\end{tabular}

COD: Chemical oxygen demand

as an adsorbent for discolouration of waste water containing indigo dye. The isotherm studies indicated that the removal of indigo dye was initial concentration dependent and an increase in the concentration led to a small decrease in the removal. Additionally, the other impurities such as surfactants were also removed during the adsorption and thus, BOD and COD values considerably decreased. The results of $C O D$ and $B O D$ measurements indicated that the other organic impurities also removed by adsorbent.

It was determined that the pumice, which is waste solid, has new application in the field of waste water treatment processes and therefore has gained an economical value.

\section{References}

[1] Wambuguh D. (2009). By-Product Synergy In The Textile Industry: Indigo Waste Recovery In The Denim Finishing Process. /PhD Thesis). The University of Texas at El Paso (USA)

[2] Lin S. H., Chen M. L. (1997). Treatment of textile wastewater by chemical methods for reuse. Water Research, 31(4), 868-876.

[3] O'Neill C., Hawkes F. R., Hawkes D. L., Lourenco N. D.,
Pinheiro H. M., Delee W. (1999). Colour in textile effluents - sources, measurement, discharge consents and simulation: a review. Journal of Chemical Technology and Biotechnology, 74(11), 1009-1018.

[4] Veliev E. V., Öztürk T., Veli S., Fatullayev A. G. (2006). Application of Diffusion Modelfor Adsorption of Azo Reactive Dye on Pumic., Polish J. Environ. Stud., 15(2), 347-353.

[5] Woerner D. L. Membrane technology in textile operations. 28/08/2014. http://cdam.minam.gob.pe/multimedia/ contaminacion_industrial/PDF\%20files/TextileMembrane. pdf

[6] Al-Qodah Z. (2000). Adsorption of dyes using shale oil ash. Water Research, 34(17), 4295-4303.

[7] Puzyn T. and Mostrag-Szlichtyng A. (Ed.). (2012). Textile Organic Dyes - Characteristics, Polluting Effects and Separation/Elimination Procedures from Industrial Effluents - A Critical Overview, Organic Pollutants Ten Years After the Stockholm Convention - Environmental and Analytical Update, InTech, ISBN: 978-953-307-917-2

[8] Sabbas T., Polettinib A., Pomi R., Astrup T., et. al. (2003). Management of municipal solid waste incineration residues. Waste Management, 23(1), 61-88.

[9] Toraman Ö. Y., Topal H. (2003). Katı atık ve arıtma çamurlarının değerlendirilmesinde alternatif termal 
teknolojiler ve uygulamaları. J. Fac. Eng. Arch. Gazi Univ., 18(1), 19-33.

[10] Sivrikaya O., Kıyıldı K. R., Karaca Z. (2014). Recycling waste from natural stone processing plants to stabilise clayey soil. Environmental Earth Science, 71(10), 43974407.

[11] Annadurai G., Juang R. S., Lee D. J. (2002). Use of cellulose-based wastes for adsorption of dyes from aqueous solutions. J. Hazard. Mater., 92(3), 263-274.

[12] Sepehr M. N., Zarrabi M., Kazemian H., Amrane A., Yaghmaian K., Ghaffari H. R. (2013). Removal of hardness agents, calcium and magnesium, by natural and alkaline modified pumice stones in single and binary systems. Applied Surface Science. 274(June), 295-305.

[13] Mohan S. V., Rao N. C., Karthikayan J. (2002). Adsorptive removal of direct azo dye from aqueous phase onto coal based sorbents: a kinetic and mechanistic study. J. Hazard. Mater., 90(2), 189-204.

[14] Chu H. C., Chen K. M. (2002). Reuse of activated sludge biomass: I. Removal of basic dyes from wastewater by biomass. Process Biochemistry, 37(6), 595-600.

[15] Harris R. G., Wells J. D., Johnson B. B. (2001). Selective adsorption of dyes and other organic molecules to kaolinite and oxide surfaces. Colloid and Surface A: Physicochemical and Engineering Aspects, 180(1-2), 131-140.

[16] Bousher A., Shen X. D., R. Edyvan G. (1997). Removal of coloured organic matter by adsorption onto low-cost waste materials. Water Research, 31(8), 2084-2092.
[17] Wu F. C., Tseng R. L., Juang R. S. (1999). Pore structure and adsorption performance of the activated carbons prepared from plum kernels. J. Hazard. Mater., 69(3), 287302.

[18] Chiou M. S., Li H. Y. (2003). Adsorption behavior of reactive dye in aqueous solution on chemical cross-linked chitosan beads. Chemosphere, 50(8), 1095-1105.

[19] Özacar M., Şengil I. A. (2003). Adsorption of reactive dyes on calcined alunite from aqueous solutions. J. Hazard. Mater., 98(1-3), 211-224.

[20] Akbal F. (2005). Adsorption of basic dyes from aqueous solution onto pumice powder. Journal of Colloid and Interface Science, 286(2),455-458.

[21] Akbal F. (2005). Sorption of phenol and 4-chlorophenol onto pumice treated with cationic surfactant. Journal of Environmental Management, 74(3), 239-244.

[22] Kitis M., Kaplan S. S., Karakaya E., Yiğit N. O., Civelekoğlu G. (2007). Adsorption of natural organic matter from waters by iron coated pumice. Chemosphere. 66(1), 130138.

[23] Wambuguh D., Chianelli R. R. (2008). Indigo dye waste recovery from blue denim textile effluent: a by-product synergy approach. New Journal of Chemistry, 32(12), 2189-2194.

[24] Tunç S., Duman O. (2009). Effects of Electrolytes on the Electrokinetic Properties of Pumice Suspensions. Journal of Dispersion Science and Technology, 30(4),548-555. 